\title{
HUBUNGAN ANTARA PENGETAHUAN KESEHATAN REPRODUKSI DAN KONTROL DIRI DENGAN PERILAKU SEKSUAL PADA REMAJA SISWA SMA X KOTA SEMARANG
}

\author{
Eka Yustrikarini Alriayulfa Rosidaningrum dan Inhastuti Sugiasih \\ Fakultas Psikologi ,Universitas Islam Sultan Agung Semarang \\ Email: inhastuti@unissula.ac.id
}

\begin{abstract}
Abstrak
Penelitian ini bertujuan untuk mengetahui hubungan antara pengetahuan kesehatan reproduksi dan kontrol diri dengan perilaku seksual pada remaja siswa SMA X Kota Semarang. Penelitian ini menggunakan metode kuantitatif korelasional. Subjek penelitian adalah siswa SMA kelas X dan XI, berusia 15 - 18 tahun yang pernah atau sedang berpacaran sebanyak 218 siswa. Pengumpulan data menggunakan skala perilaku seksual dengan daya beda aitem bergerak antara 0,386 - 0,792 dengan reliabilitas 0,941, tes prestasi mengenai pengetahuan kesehatan reproduksi dengan daya beda aitem bergerak antara 0,309-0,454 dengan reliabilitas 0,866, dan skala kontrol diri dengan daya beda aitem bergerak antara 0,322 - 0,623 dengan reliabilitas 0,783. Metode pengambilan sampel menggunakan cluster random sampling. Analisa data pada penelitian ini menggunakan analisis regresi ganda. Hasil analisis menunjukan bahwa tidak ada hubungan antara pengetahuan kesehatan reproduksi dan kontrol diri dengan perilaku seksual pada remaja siswa SMA X Kota Semarang, $R=0,160$ dan $F_{\text {hitung }}=1,387$ dengan signifikansi 0,254 $(p>0,01)$.
\end{abstract}

Kata kunci: perilaku seksual, pengetahuan kesehatan reproduksi, dan kontrol diri

\section{THE CORRELATION BETWEEN REPRODUCTIVE HEALTH KNOWLEDGE AND SELF CONTROL WITH SEXUAL BEHAVIOR IN ADOLESCENT STUDENTS SENIOR HIGH SCHOOL X SEMARANG}

\begin{abstract}
The research aimed to determine the correlation between reproductive health knowledge and self-control with sexual behavior in adolescent students senior high school $X$ Semarang. This research uses correlational quantitative method. Subject from this research are high school students of class $X$ and XI were aged $15-18$ years old, who have been or are dating which amounts 218 students. Sampling methods using cluster random sampling. Collected the data used a scale of Sexual Behavior with index discrimination items range 0,386 0,792 with reliability 0,941, Reproductive Health Knowledge with index discrimination items range 0,3090,454 with reliability 0,866, scale of Self Control with index discrimination items range 0,322 - 0,623 with reliability 0,783. Data were analyzed used multiple regression analysis. The result of analysis showed that there is no correlation between reproductive health knowledge and self-control with sexual behavior in adolescent students senior high school $X$ Semarang, $R=0,160$ and $F_{\text {hitung }}=1,387$ with significance $0,254(p>0,01)$.
\end{abstract}

Keywords: sexual behavior, reproductive health knowledge, and self control

\section{Pendahuluan}

Masa remaja merupakan peralihan antara masa kanak-kanak ke masa dewasa ditandai dengan banyaknya perbedaan yang dialami baik dalam aspek kognitif, fisik, maupun psikososial. Hurlock (2011) mengemukakan bahwa remaja berasal dari kata latin adolensence yang berarti tumbuh ataupun tumbuh menjadi dewasa dimana memiliki arti yang lebih luas guna mencapai kematangan 
Hubungan Antara Pengetahuan Kesehatan Reproduksi dan Kontrol Diri Dengan Perilaku Seksual Pada

pada aspek sosial, mental, emosional, dan fisik. Masa remaja juga sering disebut sebagai masa badai karena remaja sedang mengalami masa sulit dalam menghadapi berbagai perubahan besar dalam hidup. Salah satu masalah besar yang harus di hadapi remaja adalah pubertas.

Pubertas merupakan suatu proses yang dilewati oleh individu untuk mencapai kematangan seksual dan kemampuan melakukan reproduksi. Kematangan seksual remaja terjadi saat usia 10 sampai $161 / 2$ tahun. Pada remaja perempuan kematangan seksual ditandai dengan terjadinya menarche atau haid untuk pertama kali, sedangkan pada remaja laki-laki ditandai dengan terjadinya spermache atau mimpi basah. Seiring dengan terjadi kematangan seksual terjadi pula peningkatan hormonal berupa hormon estrogen pada perempuan dan hormon testosterone pada laki-laki. Hormon tersebut membuat remaja memiliki gairah seksual yang tinggi (Papalia, 2009).

Gairah seksual yang muncul dalam diri remaja menimbulkan perasaan tertarik pada lawan jenis. Selain itu, remaja mulai tertarik untuk membahas hal yang berhubungan dengan seksualitas. Sebuah studi menemukan bahwa ketika diberikan pilihan pada 4 program televisi, remaja lebih memilih tanyangan televisi yang berisikan konten seksualitas (Santrock, 2013). Remaja mulai menyukai aktifitas yang dilakukan dengan adanya kedekatan fisik dengan lawan jenis, selain itu remaja juga menjalin hubungan romantis dengan lawan jenis. Hubungan romantis ini diwujudkan dalam bentuk aktifitas berpacaran, sayangnya aktifitas berpacaran tidak sedikit memberikan dampak buruk pada pasangan remaja yang mengakibatkan munculnya perilaku seksual. Perilaku seksual merupakan perilaku individu karena adanya keinginan seksual, dimulai dari adanya ketertarikan, lalu berkencan kemudian bercumbu hingga berhubungan seksual(Purwoastuti, 2015).

Hasil survei yang telah dilakukan oleh LKPT (Lembaga Kajian untuk Transformasi Sosial) (Syafrudin, 2011), mengenai perilaku seksual remaja dalam berpacaran, menunjukkan bahwa yang dimulai dengan mengobrol sebanyak $24 \%$, berpegangan tangan sebanyak $16 \%$, pelukan sebanyak $13 \%$, cium pipi sebanyak $12 \%$, necking sebanyak $9 \%$, meraba organ seksual sebanyak $4 \%$, petting sebanyak $2 \%$, dan intercourse sebanyak $1 \%$.

Salah satu faktor yang mempengaruhi meningkatnya perilaku seksual karena kurangnya pengetahuan mengenai kesehatan reproduksi. Kesehatan reproduksi merupakan kondisi kesejahteraan bagi fisik, lalu mental, serta sosial secara keseluruhan dimana bukan sekedar tidak memiliki penyakit ataupun tidak cacat, melainkan berfokus pada sistem reproduksi, fungsinya, serta proses. Pengetahuan kesehatan reproduksi dianggap sebagai isu penting untuk pembangunan kesehatan dalam masyarakat, tidak hanya isu moral semata. Pengetahuan yang dimiliki remaja mengenai kesehatan reproduksi masih sangat rendah, seperti tidak mengetahui tentang masa subur dan resiko kehamilan, serta mitos yang berkembang bahwa tidak akan hamil dengan sekali berhubungan seks. Akses untuk mendapatkan informasi mengenai kesehatan reproduksi juga terbatas, baik dari orang tua, sekolah, maupun media massa. Informasi dari media massa yang tidak dibarengi dengan tingginya pengetahuan yang benar dapat memicu timbulnya perilaku seksual yang tidak bertanggung jawab (Marmi, 2015).

Faktor yang mempengaruhi perilaku seksual selain karena kurangnya informasi mengenai kesehatan reproduksi juga karena remaja kurang mampu mengontrol diri untuk melakukan hal yang buruk sehingga remaja kesulitan untuk mengontrol dorongan seksual yang dimiliki, maka hal ini akan menimbulkan perilaku seksual. Kontrol diri merupakan kemampuan yang dimiliki individu untuk mengatur,mengarahkan, serta membimbing perilaku agar sesuai dengan norma sosial yang berlaku. Peningkatan secara hormonal membuat remaja membutuhkan penyaluran dalam suatu bentuk 
perilaku tertentu. Ketidakmampuan mengendalikan dorongan seksual menyebabkan remaja melakukan aktivitas seksual, karena penyaluran dorongan seksual remaja mengalami penundaan akibat usia perkawinan yang belum terpenuhi (Irianto, 2014).

Berdasarkan penelitian sebelumnya yang telah dilakukan oleh Ayu Khairunnisa diketahui jika terdapat hubungan yang negatif antara kontrol diri dengan perilaku seksual pra-nikah pada remaja, bahwa hasil yang didapatkan apabila kontrol diri yang dimiliki individu tinggi, maka perilaku seksual pra-nikah pada remaja menjadi rendah (Khairunnisa, 2013).

Penelitian sebelumnya mengenai perilaku seksual remaja sudah pernah dilakukan antara lain oleh Kemali Syarief (2009) dengan judul Hubungan Antara Pengetahuan Tentang Kesehatan Reproduksi dengan Perilaku Seks Pra-nikah di Yayasan Perguruan Teladan Binjai dan diketahui bahwa terjadi hubungan yang berarti antara pengetahuan mengenai kesehatan reproduksi dihubungkan dengan perilaku seks pra-nikah. Penelitian serupa oleh Yulia Dewi Nurjanah (2013) dengan judul Pengaruh Pendidikan Kesehatan Reproduksi Terhadap Kecenderungan Perilaku Seksual Remaja dan hasil menunjukkan bahwa terdapatperbedaan yang berarti antara kemungkinan terjadinya perilaku seksual remaja sebelum dengan sesudah pemberian pendidikan tentang kesehatan reproduksi. Penelitian lain juga telah diteliti oleh Ayu Khairunnisa (2013) yang berjudul Hubungan Religiusitas dan Kontrol Diri dengan Perilaku Seksual Pranikah Remaja MAN 1 Samarinda, sehingga diketahui adanya hubungan negatif yang berarti jika tingginya kontrol diri pada seseorang membuat rendahnya perilaku seksual pranikah.

Berdasarkan beberapa penelitian terdahulu, perbedaan penelitin ini dengan yang sebelumnya adalah subjek, variabel, dan lokasi penelitian. Pemaparan diatas membuat peneliti berminat melakukan penelitian dengan judul hubungan pengetahuan kesehatan reproduksi dan kontrol diri dengan perilaku seksual pada remaja siswa SMA X Kota Semarang.

Penelitian ini memiliki 3 (tiga) hipotesis, yakni (1) ada hubungan antara pengetahuan kesehatan reproduksi dan kontrol diri dengan perilaku seksual pada remaja siswa SMA X Kota Semarang, (2) ada hubungan negatif antara pengetahuan kesehatan reproduksi dengan perilaku seksual pada remaja siswa SMA X Kota Semarang, dan (3) ada hubungan yang negatif antara kontrol diri dengan perilaku seksual pada remaja siswa SMA X Kota Semarang.

\section{Landasan Teori}

Menurut Sarwono (1997) perilaku seksual merupakan perilaku yang terjadi karena adanya dorongan seksual, yang dilakukan dengan sesama jenis atau lawan jenis. Perilaku seksual dapat berbagai macam, dimulai karena adanya ketertarikan kemudian melakukan kencan, bercumbu, hingga berhubungan seksual. Objek seksualnya dapat berupa orang lain maupun dirinya sendiri dalam hayalan.

Menurut Mu'tadin (Syarif, 2009) perilaku seksual merupakan semua yang berkaitan dengan alat kelamin atau hubungan seksual antara pria dan wanita.Selanjutnya, Notoatmodjo (2014) mengatakan bahwa perilaku seksual remaja merupakan segala bentuk perilaku remaja karena munculnya hasrat seksual dari dalam diri ataupun luar.

Perilaku seksual terjadi karena didasari keinginan untuk memperoleh kenikmatan seksual secara fisik, seperti tampilan disfungsi seksual dan siklus respon seksual (Sadarjoen, 2005). Menurut Rahayu (Praptiningrum, 2005) perilaku seksual adalah mulai beralihnya perhatian remaja kepada lawan jenis yang diikuti dengan saling tertarik, saling mendekati, dan memiliki keinginan untuk melakukan 80 P-ISSN 1907-8455 
Hubungan Antara Pengetahuan Kesehatan Reproduksi dan Kontrol Diri Dengan Perilaku Seksual Pada

Remaja Siswa SMA X Kota Semarang

Proyeksi Vol. 13 (1) 2018, 78-87

kontak fisik yang didorong nafsu seksual. Tahap-tahap perilaku seksual bermulai dari berpegangan tangan, pelukan, cium pipi, cium bibir, memegang alat kelamin, hingga berhubungan seksual.

Menurut Poltekes Depkes (dalam Irianto, 2014), faktor yang menyebabkan remaja melakukan hubungan seksual, yaitu adanya dorongan biologis serta ketidakmampuan dalam mengendalikan dorongan tersebut, kurangnya pengetahuan tentang kesehatan reproduksi dan adanya kesempatan untuk melakukan hubungan seksual pranikah.

Menurut WHO (dalam Maryam, 2016) kesehatan reproduksi merupakan kesejahteraan baik secara sosial,fisik, serta mental, bukan sekedar tidak memiliki penyakit ataupun tidak cacat, melainkan fokus pada hal yang berkaitan dengan fungsi, proses, maupun sistem reproduksi. Manuaba (dalam Marmi, 2015) juga mengemukakan bahwa kesehatan reproduksi merupakan kemampuan yang dimiliki individu sehingga mampu memanfaatkan alat reproduksi dengan melakukan pengukuran masa kesuburan dapat menjalani kehamilan serta persalinan dengan aman tanpa adanya resiko yang dapat membahayakan dan kemudian mengembalikkan kesehatan menjadi normal kembali.

Kesehatan reproduksi remaja (Marmi, 2015) merupakan keadaan sehat dimana berkaitan dengan fungsi, sistem, dan proses reproduksi pada remaja. Sehat bukan sekedar tidak mempunyai penyakit atau tidak cacat tetapi sehat baik mental maupun sosial kultural. Selanjutnya, menurut BKKBNUNICEF (dalam Marmi, 2015) kesehatan reproduksi remaja secara umum adalah keadaan sehat baik pada fungsi lalu sistem serta proses reproduksi pada remaja laki-laki dan perempuan saat usia 10-24 tahun. Masalah kesehatan reproduksi remaja yang kerap ditemui adalah kehamilan yang tidak dikehendaki, mengandung dan melahirkan di usia muda, permasalahan penyakit menular seksual, tindakan kekerasan seksual, free sex, aborsi, kondisi remaja yang tidak menunjang kehamilan yang sehat, dan resiko komplikasi kehamilan dan persalinan.

Calhoun dan Acocella (Ghufron, 2016) mengemukakan bahwa kontrol diri adalah mengatur pemrosesan psikologis, perilaku, sertafisik individu, sehingga dapat dikatakan suatu rangkaian proses yang membentuk diri sendiri. Averill (1973) menjelaskan bahwa kontrol diri merupakan variabel psikologis yang menunjukkan kemampuan individu dalam mengubah perilaku, serta kebisaan individu untuk mengolah informasi yang diterima baik penting ataupun tidak penting. Goldfried dan Merbaum (dalam Ghufron, 2016) mengemukakan definisi kontrol diri merupakan kemampuan yang dimiliki untuk membimbing, menyusun, mengarahkan, dan mengatur perilaku sehingga mampumembawa individu menuju arah konsekuensi yang positif. Selanjutnya Mahoney dan Thoresen (Ghufron, 2016) juga mendefinisikan bahwa kontrol diri sebagai ikatan seseorang dengan lingkungan secara keseluruhan. Tingginya kontrol diri membuat individu bisa menyesuaikan diri dengan permintaan sosial lingkungan fisik, sehingga mampu fleksibel, terbuka, memperlancar interaksi sosial, dan bersikap hangat. Praptiani (2013) mengatakan kontrol diri ialah dimana individu dapat mengendalikan perilaku agar tidak impulsif, serta mengetahui dampak dari perilaku yang dilakukan dan mencari informasi ketika akan mengambil keputusan.

Averill (1973) mengemukakan bahwa kontrol diri terdiri dari 3 (tiga) aspek, yakni (1) kontrol perilaku (behavior control). Kontrol perilaku merupakan kemampuan individu untuk bereaksi secara langsung sehingga mampu merubah atau memodifikasi situasi yang tidak menyenangkan. Kontrol perilaku terbagi 2, yaitu mengelola pelaksana (regulated administration) dan mengubah stimulus (stimulus modifiability). Kemampuan mengelola pelaksana ialah dimana individu mampu untuk mengatasi suatu situasi, baik diri sendiri ataupun aturan perilaku. Kemampuan mengubah stimulus

$$
\begin{array}{l|l}
\text { P-ISSN 1907-8455 } & 81 \\
\hline
\end{array}
$$


ialah dimana individu dapat memahami waktu serta cara yang tepat untuk menghadapi rangsangan yang tidak dikehendaki. Ada cara-cara yang dipakai, yaitu adanya batas waktu ketika situasi terjadi, menjauhi rangsangan, membatasi intensitasnya, serta menghentikan waktu saat rangsangan berlangsung. (2) Kontrol kognitif (cognitive control), yaitu individu mampu mencerna informasi yang tidak dikehendaki, melalui tahapan menilai, menghubungkan, atau menginterpretasi peristiwa dalam kerangka kognitif guna meminimalisir tekanan. Kontrol kognitif terdiri dari dua komponen, yaitu melakukan penilaian (appraisal) dan memperoleh informasi (information gain). Melakukan penilaian merupakan bentuk usaha individu untuk menafsirkan dan menilai suatu situasi dengan melihat segisegi positif secara subjektif. Informasi yang diperoleh individu tentang hal yang tidak menyenangkan mampu membuat individu mengantisipasi suatu hal dengan berbagai pertimbangan. (3) Kontrol keputusan (decisional control) yang merupakan kemampuan individu untuk memilih suatu keputusan yang sesuai dengan diri individu itu. Manfaat kontrol diri dapat maksimal ketika tersedia kebebasan, kemungkinan, atau kesempatan individu untuk menentukan pilihan.

\section{Metode Penelitian}

Populasi merupakan sekumpulan objek dalam wilayah generalisasi dari sampel penelitian yang dilakukan, dimana memiliki kualitas karakteristik yang sebelumnya telah ditetapkan peneliti (Hadi, 2000). Populasi yang digunakan adalah siswa SMA X Kota Semarang dengan karakteristik, yaitu:

a. Tercatat sebagai siswa-siswi SMA X di Semarang

b. Berusia 15 - 18 tahun

c. Pernah atau sedang memiliki pacar

Pengambilan sampel pada penelitian ini mempergunakan teknik cluster random sampling, ialah teknik pemilihan sekelompok subjek yang didasarkan jika populasi heterogen, dimana subpopulasi merupakan suatu cluster yang mempunyai sifat heterogen (Sugiyono, 2014). Metode yang akan dipergunakan untuk mengumpulkan data ialah metode skala. Metode skala ialah cara untuk mengumpulkan data penelitian dengan membuat pernyataan tertulis mengenai hal yang disajikan berbentuk daftar pernyataan dengan interval tertentu sehingga dapat menghasilkan data kuantitatif (Sugiyono, 2014). Alat ukur atau skala yang digunakan dalam penelitian ini terdiri dari skala perilaku seksual remaja, tes prestasi pengetahuan kesehatan reproduksi, dan skala kontrol diri.

\section{Hasil}

Sebelum dilakukan uji hipotesis, dilakukan uji asumsi terlebih dahulu. Uji asumsi dalam penelitian ini terdiri dari uji normalitas, linearitas dan multikolinearitas.

Uji normalitas merupakan cara yang dilakukan untuk mengetahui normal atau tidaknya distribusi data tiap variabel (Priyatno, 2016). Uji normalitas yang dipergunakan ialah teknik One-Sample Kolmogrov-Smirnov Test dengan taraf signifikansi 0,05. Suatu data dikatakan memiliki distribusi normal ketika signifikansi lebih besar dari $5 \%$ atau 0,05 .

Hasil uji normalitas yang dilakukan pada tiga variabel penelitian maka diperoleh nilai K-ZS yaitu:

Hasil dari uji normalitas yang diperoleh dari data perilaku seksual, pengetahuan kesehatan reproduksi, dan kontrol diri menunjukkan bahwa nilai K-SZ dari perilaku seksual dan pengetahuan reproduksi dibawah 0,05 yang berarti distribusi tidak normal dan nilai K-SZ dari kontrol diri diatas $0,05$ ( $p>0,05)$ yang berarti distribusi normal, maka dapat ditarik kesimpulan bahwa dua data mempunyai distribusi tidak normal dan satu data mempunyai distribusi normal. Suatu variabel dapat 82 P-ISSN 1907-8455 
Hubungan Antara Pengetahuan Kesehatan Reproduksi dan Kontrol Diri Dengan Perilaku Seksual Pada

memiliki distribusi tidak normal karena tidak terpenuhinya asumsi ataupun dasar-dasar dari asumsi tersebut. Hal lain yang juga menyebabkan suatu distribusi tidak normal yaitu munculnya beberapa outlier (keanehan) yang membuat uji normalitas menjadi gagal, jika penyimpangan yang terjadi relatif kecil maka selanjutnya melanjutkan pada analisis yang telah ditetapkan (Widhiarso W, 2012).

Uji linearitas ialah tahapan yang dilakukan pada tiap variabel apakah mempunyai hubungan yang linear atau tidak linear. Uji linearitas pada perhitungan ini mempergunakan SPSS 21.0, data yang memiliki nilai signifikansi pada $\mathrm{F}$ linearity $<0,05$ dinyatakan memiliki hubungan linearitas (Priyatno, 2016).

Berdasarkan uji linearitas antara perilaku seksual terhadap pengetahuan kesehatan reproduksi memperoleh nilai $F$ linear sebesar 1,420 . dengan taraf sigifikansi $0,236(p>0,05)$, hasil menunjukkan bahwa variabel perilaku seksual dengan variabel pengetahuan kesehatan reproduksi tidak berhubungan secara linear. Selanjutnya, dilakukan uji linearitas pada perilaku seksual terhadap kontrol diri yang diperoleh nilai $F$ linear sebesar 2,038 dengan taraf signifikansi 0,156 ( $p>0,05)$, hasil menunjukkan jika variabel perilaku seksual dengan variabel kontrol diri tidak berhubungan secara linear. Alasan yang menyebabkan suatu penelitian tidak linear karena antara variabel bebas dan variabel tergantung yang sebenarnya memiliki korelasi yang signifikan, namun karena tetap menggunakan program regresi linear walaupun data tidak linear maka tidak terdapat korelasi (Hadi S., 2001)

Uji hipotesis dalam penelitian ini menggunakan uji korelasi. Hasil uji korelasi antara pengetahuan kesehatan reproduksi dan kontrol diri dengan perilaku seksual pada remaja SMA X di kota Semarang memperoleh $R=0,160$ dan $F_{\text {hitung }}=1,387$ dengan signifikansi $0,254(p>0,01)$. Hasil tersebut menunjukkan bahwa tidak ada hubungan antara pengetahuan kesehatan reproduksi dan kontrol diri dengan perilaku seksual. Nilai koefisien prediktor pengetahuan kesehatan reproduksi sebesar 0,779 dan koefisien prediktor kontrol diri sebesar -0,414 dengan nilai konstan sebesar 14,305.

Uji korelasi pada hipotesis kedua dalam penelitian ini adalah korelasi parsial. Korelasi parsial memiliki tujuan dalam menguji apakah terdapat hubungan antara variabel bebas dan variabel tergantung, dimana salah satu variabel bebas dikendalikan. Hasil uji korelasi antara variabel perilaku seksual dengan variabel kontrol diri dengan melakukan kontrol terhadap variabel pengetahuan kesehatan reproduksi diperoleh ryı- $2=0,084$ dengan signifikansi 0,391 $(p>0,01)$. Hasil tersebut menunjukkan bahwa tidak ada hubungan yang negatif antara variabel perilaku seksual dengan variabel kontrol diri dengan melakukan kontrol terhadap pengetahuan kesehatan reproduksi.

Uji korelasi yang digunakan pada hipotesis ketiga dalam penelitian ini dilakukan antara variabel perilaku seksual dan variabel pengetahuan kesehatan reproduksi dengan melakukan kontrol terhadap variabel kontrol diri. Hasil uji korelasi antara variabel perilaku seksual dan variabel pengetahuan kesehatan reproduksi dengan melakukan kontrol terhadap variabel kontrol diri memperolehr yı-2 $=-0,113$ dengan signifikansi 0,248 $(p>0,01)$. Hasil tersebut menunjukkan bahwa tidak ada hubungan yang negatif antara variabel perilaku seksual dengan variabel pengetahuan kesehatan reproduksi dengan melakukan kontrol terhadap variabel kontrol diri.

Berdasarkan deskripsi skor pada skala perilaku seksual pada penelitian ini diketahui bahwa $39,81 \%$ subjek berpegangan tangan, $13,88 \%$ subjek melakukan aktivitas berperlukan, $13,88 \%$ subjek mencium pipi pasangan, 8,33\% subjek berciuman bibir, 1,85\% subjek memegang alat kelamin, dan $1 \%$ subjek melakukan aktivitas berhubungan seksual. Hasil tersebut menunjukkan bahwa paling 
banyak subjek melakukan pegangan tangan, sedangkan paling sedikit subjek melakukan hubungan seksual.

Deskripsi skor tes prestasi pengetahuan kesehatan reproduksi yang dihasilkan berdasarkan data empirik diperolehskor minimal sebesar 15 , skor maksimal sebesar 24 , mean sebesar 21,44 dan standar deviasi sebesar 1,992. Berdasarkan norma kategorisasi distribusi normal kelompok sampel dalam penelitian ini dapat diketahui rentang skor sampel berada dalam kategorisasi sangat tinggi yaitu 21,44 yang didasarkan pada mean empiriknya.

Berdasarkan norma kategorisasi skala kontrol diri, distribusi normal kelompok sampel dalam penelitian ini dapat diketahui rentang skor sampel berada dalam kategorisasi tinggi yaitu 57,81 yang didasarkan pada mean empiriknya. Adapun norma kategorisasi yang digunakan sebagai deskripsi data variabel secara keseluruhan tersaji dalam tabel dibawah ini:

Tabel 1. Kategorisasi skor subjek skala kontrol diri

\begin{tabular}{llll}
\hline Norma & Kategorisasi & Jumlah & Persentase \\
\hline $61,2<x \leq 72$ & Sangat tinggi & 25 & $23,1 \%$ \\
$50,4<x \leq 61,2$ & Tinggi & 74 & $68,5 \%$ \\
$39,6<x \leq 50,4$ & Sedang & 9 & $8,3 \%$ \\
$28,8<x \leq 39,6$ & Rendah & 0 & $0 \%$ \\
$18<x \leq 28,8$ & Sangat rendah & 0 & $0 \%$ \\
& Total & 108 & $100 \%$ \\
\hline
\end{tabular}

\section{Pembahasan}

Hasil uji hipotesis pertama menunjukkan nilai korelasi $R=0,106$ dan $F_{\text {hitung }}=1,387$ dengan $p=$ $0,254(p>0,01)$. Hasil perhitungan tersebut menggunakan teknik analisis regresi dua prediktor yang menunjukkan bahwa tidak ada hubungan antara pengetahuan kesehatan reproduksi dan kontrol diri dengan perilaku seksual pada remaja siswa SMA X di kota Semarang. Koefisien $R$ Square untuk pengetahuan kesehatan reproduksi dan kontrol diri diperoleh 0,026.

Hipotesis kedua dilakukan dengan perhitungan korelasi parsial pada variabel kontrol diri dan variabel perilaku seksual dengan melakukan kontrol terhadap variabel pengetahuan kesehatan reproduksi diperoleh ryı-2 $=0,084$ dengan signifikansi $0,391(p>0,01)$. Hasil menunjukkan bahwa tidak ada hubungan negatif antara variabel kontrol diri dengan variabel perilaku seksual dengan melakukan kontrol terhadap variabel pengetahuan kesehatan reproduksi.

Hasil yang ditunjukkan pada penelitian sebelumnya yang telah dilakukan oleh Bakti (2010) bahwa tidak ada korelasi yang berarti antara tingkat pengetahuan kesehatan reproduksi dengan perilaku seksual remaja. Terdapat beberapa hal yang mempengaruhi pengetahuan seseorang yaitu pendidikan, informasi, pengalaman, sosial ekonomi, dan lingkungan budaya remaja.Remaja mendapatkan pengetahuan dari berbagai sumber seperti guru, internet, orang tua, dan teman sebaya. Guru memberikan informasi kepada para siswa melalui proses pembelajaran ketika menempuh suatu pendidikan (Notoatmodjo, 2003). Ketidaktahuan orang tua mengenai masalah reproduksi atau sikap orang tua yang tabu untuk membicarakan permasalahan reproduksi pada anak (Sarwono S. W., 2000). Informasi yang remaja peroleh dari orang tua $(29,1 \%)$ yang memiliki prosentase lebih kecil jika dibandingkan dengan informasi yang remaja peroleh dari media cetak $(45,5 \%)$, petugas kesehatan $(43,6 \%)$ serta teman $(34,5 \%)$. 
Hubungan Antara Pengetahuan Kesehatan Reproduksi dan Kontrol Diri Dengan Perilaku Seksual Pada

Remaja Siswa SMA X Kota Semarang

Proyeksi Vol. 13 (1) 2018, 78-87

Notoadmodjo (2007) berpendapat bahwa praktek kesehatan seseorang masih rendah, meskipun mereka memiliki pengetahuan kesehatan yang tinggi.Tidak terjadi korelasi yang berarti antara pengetahuan kesehatan reproduksi dengan perilaku seksual remaja menunjukkan jika ada faktorfaktor lain yang lebih mempengaruhi perilaku seksual jika dibandingkan dengan pengetahuan kesehatan reproduksi. Sarwono (2002) mengungkapkan bahwa terdapat beberapa faktor yang mempengaruhi munculnya permasalahan seksual pada remaja terutama dalam perilaku seksual, yang salah satunya karena kurangnya informasi mengenai seks. Menurut Muzayyanah (2008) menganalisa bahwa pelaksanaan pendidikan seksual dilakukan untuk memberikan kesadaran pada remaja bahwa yang memiliki kendali pada tubuh mereka adalah diri mereka sendiri bukan pacar, teman, ataupun orang tua.

Meskipun dalam penelitian ini menunjukkan hasil tingkat pengetahuan kesehatan reproduksi sangat tinggi, namun tidak memberikan sumbangan yang efektif pada rendahnya tingkat perilaku seksual remaja. Hal tersebut sesuai dengan hasil penelitian ini bahwa tidak ada hubungan antara variabel pengetahuan kesehatan reproduksi dengan variabel perilaku seksual.

Uji korelasi parsial digunakan untuk menguji hipotesis ketiga pada variabel pengetahuan kesehatan reproduksi dan variabel perilaku seksual dengan melakukan kontrol terhadap variabel kontrol diri diperoleh ryı-2 $=-0,113$ dengan signifikansi 0,248 $(p>0,01)$. Hal tersebut menunjukkan bahwa tidak ada hubungan yang negatif antara variabel pengetahuan kesehatan reproduksi dan variabel perilaku seksual dengan melakukan kontrol terhadap kontrol diri.

Hasil penelitian ini diperkuat dengan penelitian sebelumnya dari Rafiyanti dan Wiwien (Rafiyanti, 2012)bahwa tidak terjadi hubungan antara kontrol diri dengan perilaku seksual pranikah. Tidak terjadinya korelasi antara kontrol diri dengan perilaku seksual pranikah menunjukkan jika terdapat faktor selain kontrol diri yang berpengaruh pada perilaku seksual pranikah. Sarwono (2000) berpendapat bahwa terdapat faktor lain yang membuat rendahnya perilaku seksual yaitu adanya nilai moral pada masyarakat. Nilai yang memegang teguh bahwa berhubungan intim sebelum menikah merupakan hal yang dilarang, dengan diwujudkan oleh para perempuan yang menjaga kesuciannya hanya untuk suaminya kelak. Noibi (Reiss, 2004)yang mengatakan bahwa perilaku seksual mendapat pengaruh oleh tabu atau larangan untuk memperbincangkan persoalan seksual.

Meskipun dalam hasil penelitian ini tingkat dari kontrol diri termasuk tinggi, namun tidak memberikan sumbangan pada rendahnya tingkat perilaku seksual sesuai dengan hasil hipotesis yang menunjukkan bahwa tidak ada hubungan antara variabel kontrol diri dengan variabel perilaku seksual.

Hasil uji normalitas dalam penelitian ini menunjukkan bahwa variabel perilaku seksual dan pengetahuan kesehatan reproduksi remaja memiliki nilai K-SZ 0,000 $(p<0,05)$ yang artinya memiliki distribusi tidak normal sedangkan variabel kontrol diri memiliki nilai K-SZ 0,579 ( $p>0,05)$ yang artinya memiliki distribusi normal. Suatu varibel dapat memiliki distribusi tidak normal karena tidak terpenuhinya asumsi ataupun dasar-dasar dari asumsi tersebut. Ketika asumsi yang dianggap sebagai prasyarat dari sejumlah model analisis tidak terpenuhi, maka terdapat alternatif untuk mengatasinya yang pertama mengganti teknik analisis data dari yang sebelumnya parametrik ke non parametrik yang setara. Namun, mengganti teknik analisis data dari parametrik ke non parametrik banyak sekali menimbulkan kesulitan karena non parametrik memiliki kemampuan yang amat terbatas. Kedua tetap menggunakan hasil analisis yang sama tetapi dengan interpretasi yang longgar (interpretasi konservatif) terhadap hasil analisinya, kehati-hatian ini dilakukan dengan lebih baik mengatakan

$$
\begin{array}{l|l}
\text { P-ISSN 1907-8455 } & 85
\end{array}
$$


tidak ada perbedaan atau tidak ada korelasi ketika hasil dari pengujian berada diambang batas penerimaan atau penolakan hipotesis. Untuk selanjutnya menyatakan kesimpulan dengan adanya perbedaan atau korelasi belum kongklusif tetapi baru indikatif yang untuk selanjutnya harus di konfirmasi dalam penelitian-penelitian selanjutnya (Hadi S. , 2001). Beberapa hal yang terjadi ketika suatu distribusi tidak normal, seperti data berasal dari distribusi lain yang memang tidak teridentifikasi, munculnya satu atau beberapa outlier (keanehan) yang kemungkinan menyebabkan uji normalitas gagal, apabila terdapat penyimpangan dari normalitas relatif kecil maka cenderung untuk tidak melakukan apa-apa sehingga melanjutkan pada analisis yang telah ditetapkan, dan beralih ke uji non parametrik yang tidak mengasumsikan distribusi normal (Widhiarso W, 2012).

Hasil uji linearitas menunjukkan bahwa perilaku seksual terhadap pengetahuan kesehatan reproduksi memperoleh nilai $F$ linear sebesar 1,420 dengan taraf signifikansi 1,236 $(p>0,05)$ dan dalam uji linearitas kepada perilaku seksual terhadap kontrol diri yang diperoleh $\mathrm{F}$ linear sebesar $2,038$ dengan taraf signifikansi sebesar 0,156 ( $p>0,05)$. Kedua hasil uji linearitas tersebut menunjukkan bahwa keduanya tidak linear, dalam hal ini terdapat beberapa alasan sehingga suatu penelitian menjadi tidak linear. Pertama, antara variabel $X$ dan $Y$ memang tidak berkorelasi atau korelasinya memanglah sangat rendah. Kedua, antara variabel $X$ dan $Y$ sebenarnya memiliki korelasi yang signifikan atau bahkan sangat signifikan, tetapi karena data yang dimiliki tidak linear dan kita ingin menggunakan program regresi linear, maka korelasi tidak dapat terjadi atau dapat dikatakan sangat underestimed. Hal ini sebaiknya dilakukan uji linearitas untuk menentukan terlebih dahulu mungkin tidaknya suatu data linear atau tidak. Suatu data menjadi tidak linear karena data pangkat dua (kuadratik), pangkat tiga (kubik), pangkat empat (kuartik) atau lebih tinggi (Hadi S. , 2001).

Berdasarkan hasil pengujian data diatas menunjukkan bahwa ketiga hipotesis yang diajukan oleh peneliti ditolak yaitu tidak ada hubungan antara pengetahuan kesehatan reproduksi dan kontrol diri dengan perilaku seksual pada remaja siswa SMA X kota Semarang. Apabila dalam penelitian hipotesis yang diajukan ditolak atau tidak terbukti, maka perlu dilakukan pengecekan mengenai ada tidaknya kesalahan dalam penggunaan teori, instrumen, pengumpulan data, analisis data, ataupun rumusan masalah yang diajukan (Sugiyono, 2014).

\section{Daftar Pustaka}

Alwi, H. dkk. (2003). Kamus besar bahasa indonesia. Jakarta: Balai Pustaka.

Angelina, D. Y. (2013). Pola asuh otoriter, kontrol diri, dan perilaku seks bebas remaja smk. Persona, Jurnal Psikologi Indonesia, 2(2), 173-182.

Averill, J. (1973). Personal control over aversive stimuli and its relationship to stress. Psychological Bulletin, 286 - 303.

Azwar, S. (2005). Metode penelitian. Yogyakarta: Pustaka Pelajar.

Bakti, M. (2010). Hubungan antara tingkat pengetahuan kesehatan reproduksi dengan perilaku seksual remaja siswa-siswi SMAN 1 Sukoharjo.Skripsi. Universitas Sebelas Maret, Surakarta.

Ghufron, M. N. (2016). Teori-teori psikologi. Jogjakarta: AR-RUZZ MEDIA.

Hadi, S. (2000). Metodologi research jilid 2. Yogyakarta: Andi Offset.

Imron, A. (2012). Pendidikan kesehatan reproduksi remaja: peer educator \& efektivitas program pikkrr di sekolah. Jogjakarta: AR-RUZZ MEDIA.

Irianto, K. (2014). Kesehatan reproduksi reproductive health teori \& praktikum. Bandung: Alfabeta 
Hubungan Antara Pengetahuan Kesehatan Reproduksi dan Kontrol Diri Dengan Perilaku Seksual Pada

Remaja Siswa SMA X Kota Semarang

Proyeksi Vol. 13 (1) 2018, 78-87

Kartika, R. C. (2013). Hubungan pengetahuan remaja tentang kesehatan reproduksi dengan perilaku seks pranikah pada siswa kelas xi di sma n colomadu. GASTER, 10(1), 77-83.

Khairunnisa, A. (2013). Hubungan religiusitas dan kontrol diri dengan perilaku seksual pranikah remaja di man 1 samarinda. eJournal Psikologi, 1(2), 220-229.

Kumalasari, I. \& Andhyantoro, I. (2013). Kesehatan reproduksi untuk mahasiswa kebidanan dan keperawatan. Jakarta: Salemba Medika.

Kusmiran, E. (2011). Kesehatan reproduksi remaja dan wanita. Jakarta: Salemba Medika.

Marmi. (2015). Kesehatan reproduksi. Yogyakarta: Pustaka Pelajar.

Maryam, S. (2016).Gizi dalam kesehatan reproduksi. Jakarta: Salemba Medika.

Mayasari, F. \& Hadjam, M. (2000). Perilaku seksual remaja dalam berpacaran ditinjau dari harga diri berdasarkan jenis kelamin. Jurnal Psikologi, 1(2), 120-127.

Muzayyanah, S. N. (2008). Pendidikan kesehatan reproduksi remaja: bagaimana menyikapinya?. http://halalsehat.com/index.php/anak-sehat/pendidikan-kesehatan-reproduksi-remajabagaimana-menyikapinya.html

Notoatmodjo, S. (2003). Pendidikan dan perilaku kesehatan. Jakarta: PT Rineka Cipta.

Nurjanah, Y. D. (2013). Pengaruh pendidikan kesehatan reproduksi terhadap kecenderungan perilaku seksual remaja. Skripsi. Universitas Muhammadiyah, Surakarta.

Papalia, D. E., \& Feldman, R. D. (2009). Human development perkembangan manusia(Alih bahasa: A.K.Anwar). Jakarta: Salemba Humanika.

Praptiani, S. (2013). Pengaruh kontrol diri terhadap agresivitas remaja dalam mengahadapi konflik sebaya. Jurnal Sains dan Praktik Psikologi, 1-3.

Praptiningrum, N. D. (2005). Perilaku seksual anak tuna grahita pada masa remaja. Jurnal Pendidikan Khusus, 1(1), 75-87.

Priyatno, D. (2016). Spss handbook: analisis data, olah data, dan penyelesaian kasus-kasus statistik. Yogyakarta: MediaKom.

Purwoastuti, E. \&. (2015). Panduan materi kesehatan reproduksi dan keluarga berencana. Yogyakarta: PUSTAKABARUPRESS.

Rafiyanti, R. \&. (2012). Hubungan antara kontrol diri dengan perilaku seksual pranikah pada mahasiswa.Skripsi.Universitas Muhammadiyah Surakarta, Surakarta.

Reiss, M. \&. (2004). Sex education. Yogyakarta: Alenia Press.

Setiyaningrum, E. (2015). Pelayanan keluarga berencana dan kesehatan produksi--revisi. Jakarta: TIM.

Soetjiningsih. (2004). Tumbuh kembang remaja dan pemasalahannya. Jakarta: CV. Sagung Seto.

Sugiyono. (2014). Metode penelitian kuantitatif kualitatif dan rnd. Bandung: Alfabeta.

Suryabrata. (1997). Proses belajar mengajar di sekolah. Jakarta: Rineka Cipta.

Syafrudin, dkk. (2011). Himpunan penyuluhan kesehatan (pada remaja, keluarga, lansia, dan masyarakat). Jakarta: Trans Info Media.

Syarif, K. (2009). Hubungan antara pengetahuan tentang kesehatan reproduksi dengan periaku seks pra-nikah di yayasan perguruan teladan binjai.Jurnal Intelektual, 4(4), 33-39.

Wardhani, D. T. (2012). Perkembangan dan seksualitas remaja. Informasi, 17(3), 184-190. 